\title{
Epicatechins Purified from Green Tea (Camellia sinensis) Differentially Suppress Growth of Gender-Dependent Human Cancer Cell Lines
}

\author{
Mepur H. Ravindranath ${ }^{1}$, Thiruverkadu S. Saravanan ${ }^{1}$, Clarence C. Monteclaro ${ }^{1}$, \\ Naftali Presser ${ }^{1}$, Xing Ye ${ }^{1}$, Senthamil R. Selvan ${ }^{2}$ and Stanley Brosman ${ }^{3}$ \\ ${ }^{1}$ Department of Glycoimmunotherapy, John Wayne Cancer Institute, Santa Monica, CA, ${ }^{2}$ Cell Biology Laboratory, \\ Hoag Cancer Center, Hoag Memorial Hospital Presbyterian, Newport Beach, CA and ${ }^{3}$ Pacific Clinical \\ Research, Santa Monica, CA
}

\begin{abstract}
The anticancer potential of catechins derived from green tea is not well understood, in part because catechin-related growth suppression and/or apoptosis appears to vary with the type and stage of malignancy as well as with the type of catechin. This in vitro study examined the biological effects of epicatechin (EC), epigallocatechin (EGC), EC 3-gallate (ECG) and EGC 3-gallate (EGCG) in cell lines from human gender-specific cancers. Cell lines developed from organ-confined (HH870) and metastatic (DU145) prostate cancer, and from moderately (HH450) and poorly differentiated (HH639) epithelial ovarian cancer were grown with or without EC, EGC, ECG or EGCG. When untreated cells reached confluency, viability and doubling time were measured for treated and untreated cells. Whereas EC treatment reduced proliferation of HH639 cells by 50\%, EGCG suppressed proliferation of all cell lines by 50\%. ECG was even more potent: it inhibited DU145, HH870, HH450 and HH639 cells at concentrations of 24, 27, 29 and $30 \mu \mathrm{M}$, whereas EGCG inhibited DU145, HH870, HH450 and HH639 cells at concentrations 89, 45, 62 and $42 \mu \mathrm{M}$. When compared with EGCG, ECG more effectively suppresses the growth of prostate cancer and epithelial ovarian cancer cell lines derived from tumors of patients with different stages of disease.
\end{abstract}

Keywords: Green tea - epicatechin (EC) - epigallocatechin (EGC) - EC 3-gallate (ECG) - EGC 3-gallate (EGCG) - organ-confined - metastatic - prostate cancer - epithelial ovarian cancer viability - doubling time $-50 \%$ inhibitory concentration (IC50)

\section{Introduction}

There is accruing evidence that green tea may have anticancer activity (1), but the mechanisms for this action are poorly understood. Green tea is produced from the shrub Camellia sinensis (Fig. 1); leaves are dried but not fermented so that the green coloration attributed to polyphenols is retained. Commercially prepared green tea extracts contain $\sim 60 \%$

For reprints and all correspondence: Mepur H. Ravindranath, Department of Glycoimmunotherapy, John Wayne Cancer Institute, 2200 Santa Monica Boulevard, Santa Monica, CA 90404-2302, USA. Tel: +1-310-449-5263; Fax: +1-310-449-5259; E-mail: Ravindranathm@jwci.org polyphenols (1). These polyphenols are the source of bioflavonoids, which have strong antioxidant activity.

The major bioflavonoids in green tea are epicatechins. Like all bioflavonoids, the tea catechins have three hydrocarbon rings; hydroxyl molecules are found at the 3, 5, and 7 positions (Fig. 2). The four major tea catechins are epicatechin (EC), EC 3-gallate (ECG), epigallocatechin (EGC) and EGC 3-gallate (EGCG). The relative proportions of EC, ECG, EGC and EGCG in non-decaffeinated green tea are $792 \pm 3$, $1702 \pm 16,1695 \pm 1$ and $8295 \pm 92 \mathrm{mg} 100 \mathrm{~g}^{-1}$ dry wt, respectively; corresponding proportions in non-decaffeinated black tea are $240 \pm 1,761 \pm 4,1116 \pm 24$ and $1199 \pm$ $0.12 \mathrm{mg} 100 \mathrm{~g}^{-1}$ dry wt (1).

(C) The Author (2006). Published by Oxford University Press. All rights reserved.

The online version of this article has been published under an open access model. Users are entitled to use, reproduce, disseminate, or display the open access version of this article for non-commercial purposes provided that: the original authorship is properly and fully attributed; the Journal and Oxford University Press are attributed as the original place of publication with the correct citation details given; if an article is subsequently reproduced or disseminated not in its entirety but only in part or as a derivative work this must be clearly indicated. For commercial re-use, please contact journals.permissions@oxfordjournals.org 


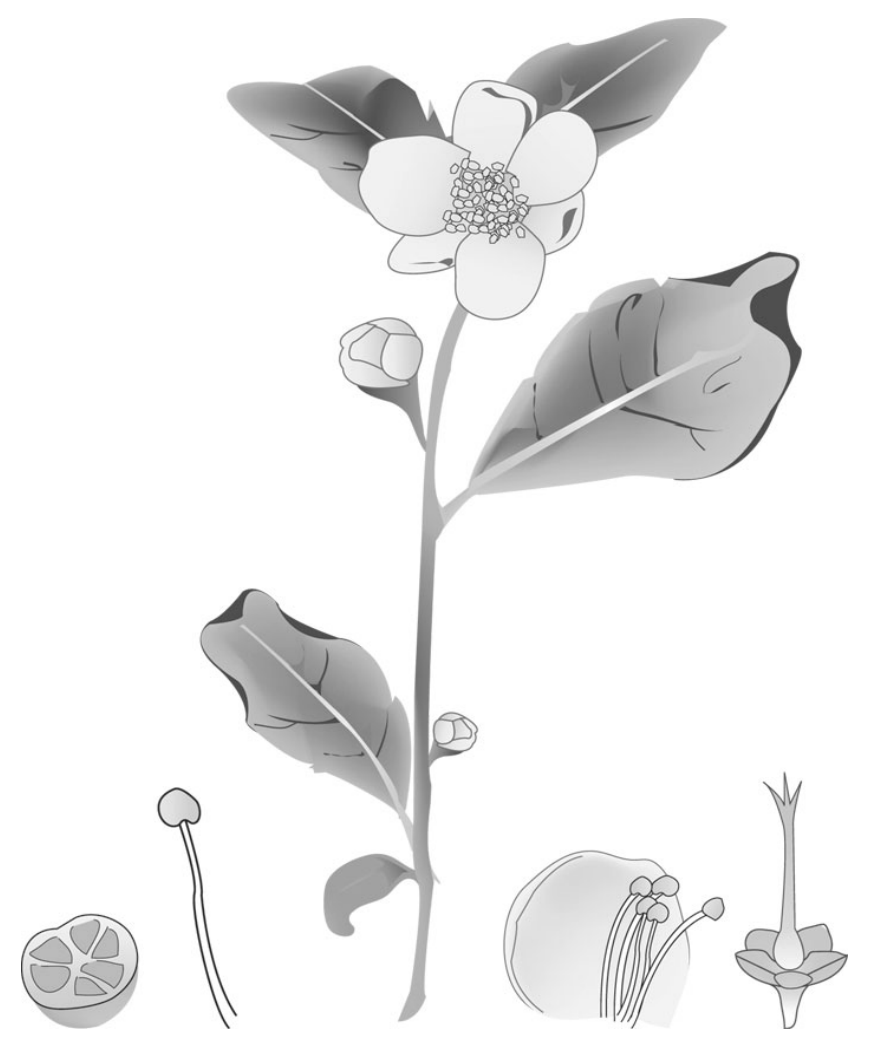

Figure 1. Morphology of Green Tea, Camellia sinensis.<smiles>C#[Al]C1Cc2c(O)cc(O)cc2O[C@H]1c1ccc(O)c(O)c1</smiles><smiles>Oc1cc(O)c2c(c1)O[C@H](c1cc(O)c(O)c(O)c1)[C@H](O)C2</smiles><smiles>O=C(O[C@@H]1Cc2c(O)cc(O)cc2O[C@@H]1c1ccc(O)c(O)c1)c1cc(O)c(O)c(O)c1</smiles>
(-)-ECG<smiles>O=C(O[C@@H]1Cc2c(O)cc(O)cc2O[C@@H]1c1cc(O)c(O)c(O)c1)c1cc(O)c(O)c(O)c1</smiles>

Figure 2. Structure of epicatechin (EC), epigallocatechin (EGC), epicatechin gallate (ECG) and epigallocatechin gallate (EGCG) used in this investigation. All bioflavanoids have three rings; tea catechins are flavan-3-ols with an hydroxyl group at the 3,5 and 7 positions.

Epicatechins have apparent activity against human cancer: they reportedly may promote apoptosis (2-6), arrest metastasis by inhibiting metalloproteinases $(7,8)$, impair angiogenesis $(9,10)$ and reverse multidrug resistance $(11,12)$. Although all epicatechins except EC can potentially suppress cell proliferation (13-18), EGCG appears the most promising and is therefore under clinical investigation in chemoprevention trials (19). However, given the wide range in physiologic potency of the different catechins, an exclusive focus on EGCG is probably short-sighted. EGCG is reportedly more effective than EGC in decreasing the intestinal absorption of cholesterol (20) and it is the most potent catechin inhibitor of HIV-1 reverse transcriptase (21), but ECG has the strongest collagenase inhibitory effect (22) and the highest antioxidant potential (23). By contrast, only EGC is a potent mediator of oxidative modification and an inhibitor of xanthine oxidase during hepatic catabolism of purines (24).

We hypothesized that the in vitro anticancer action of the various catechins varies with the type and stage of malignancy. We tested this hypothesis by examining proliferation of catechin-treated cell lines derived from organ-confined or metastatic prostate cancer $(\mathrm{CaP})$ and from moderately or poorly differentiated epithelial ovarian cancer (EOC). The goal was to obtain data that would be useful for developing chemopreventive and therapeutic clinical trials in patients with gender-specific and non-specific solid tumors.

\section{Materials and Methods}

\section{Human Cancer Cell Lines}

Four gender-specific human cancer cell lines were used. The HH870 androgen-receptor-negative $\mathrm{CaP}$ cell line was developed at Hoag Cancer Center, Newport Beach, CA, from an organ-confined primary tumor that had been resected from a 56-year-old, previously untreated Caucasian (25). This tumor was Gleason Grade 3/4, with no evidence of vascular or perineural invasion or extracapsular extension (stage T2b). The DU145 metastatic CaP cell line (American Type Culture Collection line HTB-81) was derived from a brain lesion of 69-year-old male Caucasian. It is androgen insensitive and does not express prostate-specific antigen. Two EOC cell lines developed at Hoag Cancer Center were also used: HH639 was from a poorly differentiated clear cell, Grade 3 carcinoma in the omentum and left ovary of a 56year-old Caucasian female; HH450 was from moderately differentiated metastatic cells recovered from the abdominal fluid of a 52-year-old Asian female.

All four cell lines were cryopreserved in liquid nitrogen freezer at $-70^{\circ} \mathrm{C}$. For recovery of cryopreserved cells, the vials were transferred to a $37^{\circ} \mathrm{C}$ water bath for $15-30 \mathrm{~s}$, further thawed at room temperature and then transferred to a $15 \mathrm{ml}$ polypropylene tube with a Pasteur pipette. An aliquot of $9 \mathrm{ml}$ of RPMI-9\% fetal bovine serum (FBS) was added in drops. The cells were allowed to settle for $5 \mathrm{~min}$ and then centrifuged at $4^{\circ} \mathrm{C}$ for $10 \mathrm{~min}$ at $300 \mathrm{~g}$. Supernatant was removed, and cells were suspended in fresh RPMI, gently tapped and vortexed. Cell viability was monitored by $0.2 \%$ trypan blue dye exclusion, and cell count was determined using a hemocytometer. 


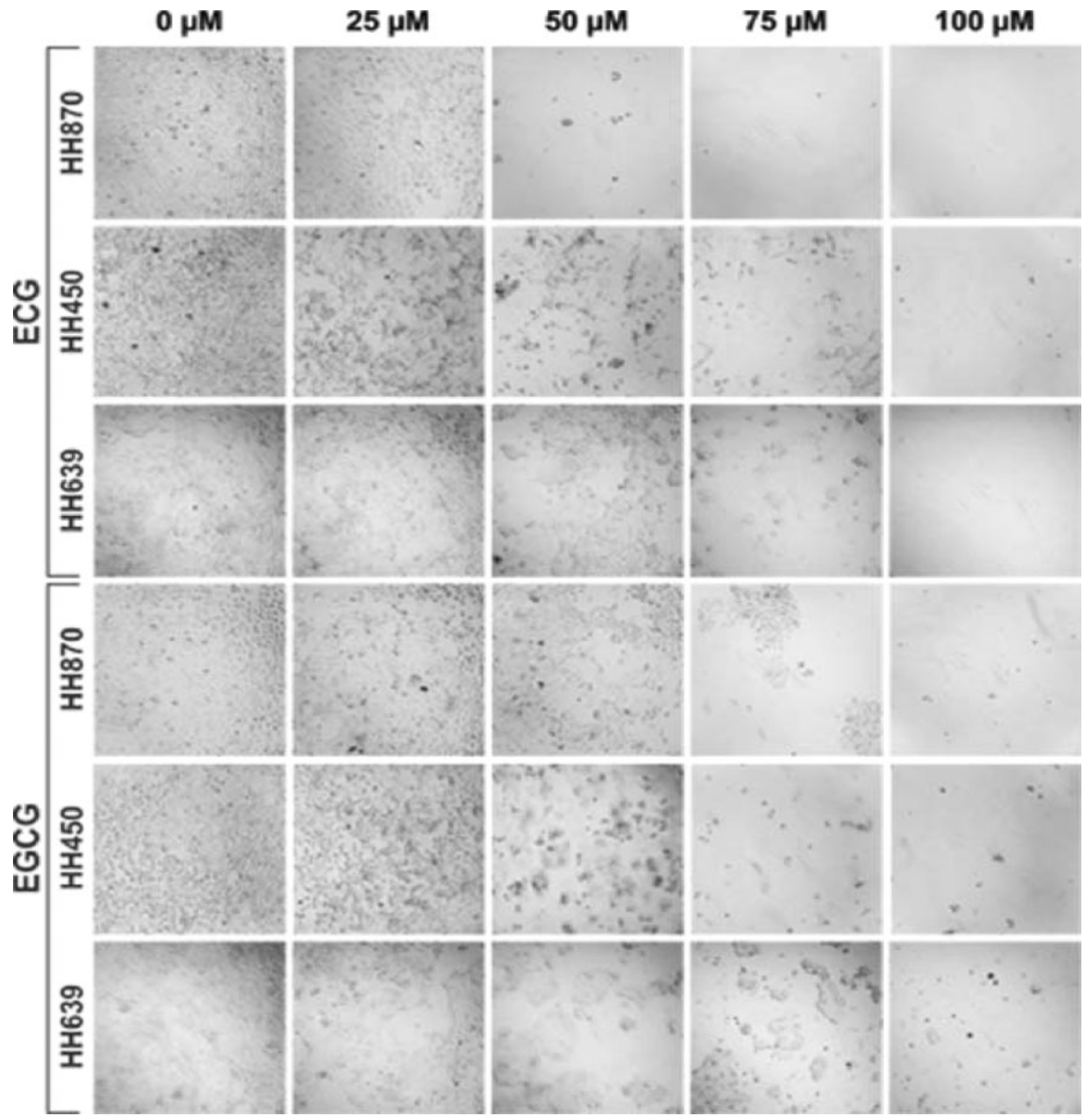

Figure 3. Photomicrographs of cells grown in culture with $0,25,50,75$ or $100 \mu \mathrm{M}$ of ECG or EGCG. Organ-confined prostate cancer cell line HH870 and primary and metastatic epithelial ovarian cancer cell lines (HH450 and HH639) were seeded $\left(2.5 \times 10^{5}\right.$ cells per line) into flasks containing culture medium (RPMI-1640 with 9\% FBS-antibiotics) with or without ECG or EGCG. When growth of untreated (control) cells reached confluency, cell monolayers in each flask were photographed under a light microscope. Both ECG and EGCG significantly affected the density of each cell line. Decrease in cell density was observed at higher concentrations of ECG and EGCG. Magnification: $\times 100$.

Cells recovered from cryovials were grown in RPMI-1640 with glutamine (Invitrogen, Carlsbad, CA) supplemented with $9 \%$ FBS, HEPES buffer, gentamycin $(5 \mathrm{mg} \%)$ and fungizone $(0.5 \mathrm{mg} \%)$, at $37^{\circ} \mathrm{C}$ in a humidified atmosphere of $5 \%$ $\mathrm{CO}_{2}$. Upon confluency, cells were detached with sterile EDTA-dextrose (137 mM sodium chloride, $5.4 \mathrm{mM}$ potassium chloride, $5.6 \mathrm{mM}$ dextrose, $0.54 \mathrm{mM}$ ethylene diamine tetra acetate (EDTA), $7.1 \mathrm{mM}$ sodium bicarbonate) at $37^{\circ} \mathrm{C}$ for 5-15 min (or 45 min for HH639), recovered with cold RPMI-1640-9\% FBS and resuspended in the same medium. Use of trypsin was avoided for harvesting the cells. Cell viability and cell count were reassessed before cells were seeded in culture flasks.

\section{Tea Epicatechins}

All epicatechins used in this study (Fig. 2) were obtained from Sigma (EC, Sigma E4018; FW 290.3; ECG , Sigma E3892, FW 442.4; EGC, Sigma E3768, FW 306.3; EGC, Sigma E4143, FW 458.4) and were 98\% pure as assessed by highperformance liquid chromatography (by the commercial source). Stock solutions were prepared under sterile conditions 

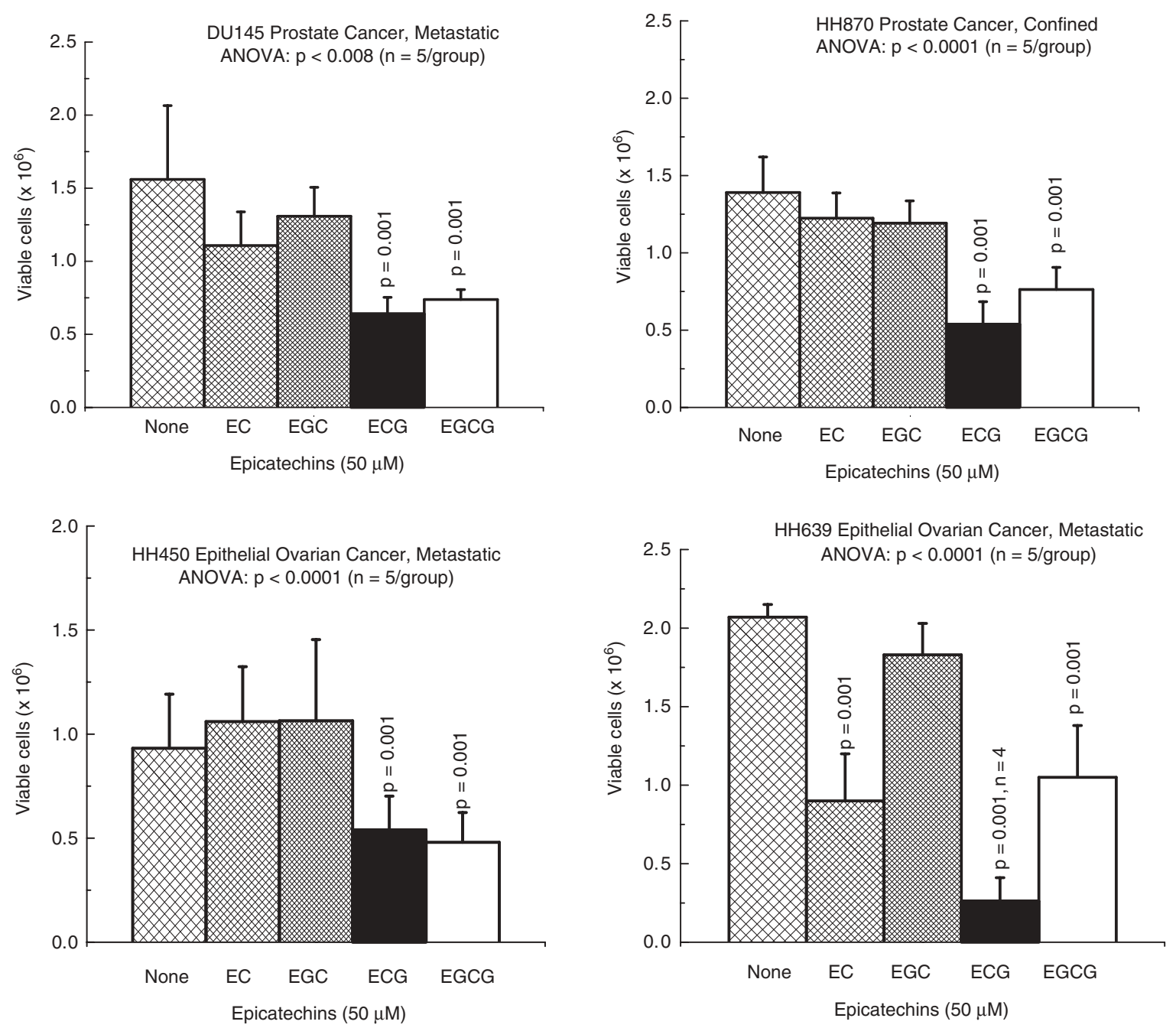

Figure 4. Density of cancer cells seeded $\left(2.5 \times 10^{5}\right.$ cells per line) into flasks containing culture medium (RPMI-1640 with $9 \%$ FBS-antibiotics) with or without catechins $(50 \mu \mathrm{M})(n=5$ per treatment). When growth of untreated cells reached confluency, cells from each flask were harvested and viable/dead cells were counted. Mean and standard deviation are represented. $P$-values obtained with pairwise comparison and ANOVA are shown.

with 50,60 or $100 \mu \mathrm{M}$ of each epicatechin or with no epicatechin (control) in RPMI-1640 with glutamine (Invitrogen), $9 \%$ FBS, $0.54 \%$ HEPES buffer, gentamycin $(5 \mathrm{mg} \%)$ and fungizone $(0.5 \mathrm{mg} \%)$.

\section{Growth Conditions}

All experiments used $25 \mathrm{ml}$ sterile polystyrene tissue culture flasks with a vented blue plug seal cap (Beckton Dickinson, Franklin Lakes, NJ, Cat. No. 353107). Each flask contained stock solution with or without epicatechin in concentrations of $50 \mu \mathrm{M}$ (five flasks for each epicatechin and five flasks for control) and 25, 75 and $100 \mu \mathrm{M}$ (three flasks for each epicatechin and three flasks for control). Cells $\left(0.25 \times 10^{6}\right)$ suspended in $10 \mathrm{ml}$ of the RPMI-1640-FBS solution described above were transferred to each flask and allowed to grow until control cells reached confluency. The cells were detached with sterile
EDTA-dextrose at $37^{\circ} \mathrm{C}$ for $5 \mathrm{~min}$, recovered with cold RPMI1640-FBS medium and resuspended in the same medium.

Cells were counted using a hemocytometer; trypan blue dye exclusion was used to determine the number of viable versus dead cells. The interval between seeding and confluent growth of control cells was used to calculate the doubling time and the number of cell cycles. The 50\% inhibitory concentration (IC50) of each catechin in each cell line was calculated using a software program (Microcal Origin Corp, OriginLab Corporation, Northampton, MA). The cells were photographed directly from the flask using light microscopy (Olympus IX-70, Japan).

\section{Statistics}

Analyses of variance and Fisher's least significant difference (LSD) method were used for pairwise comparisons of values significant at the 0.05 level. 

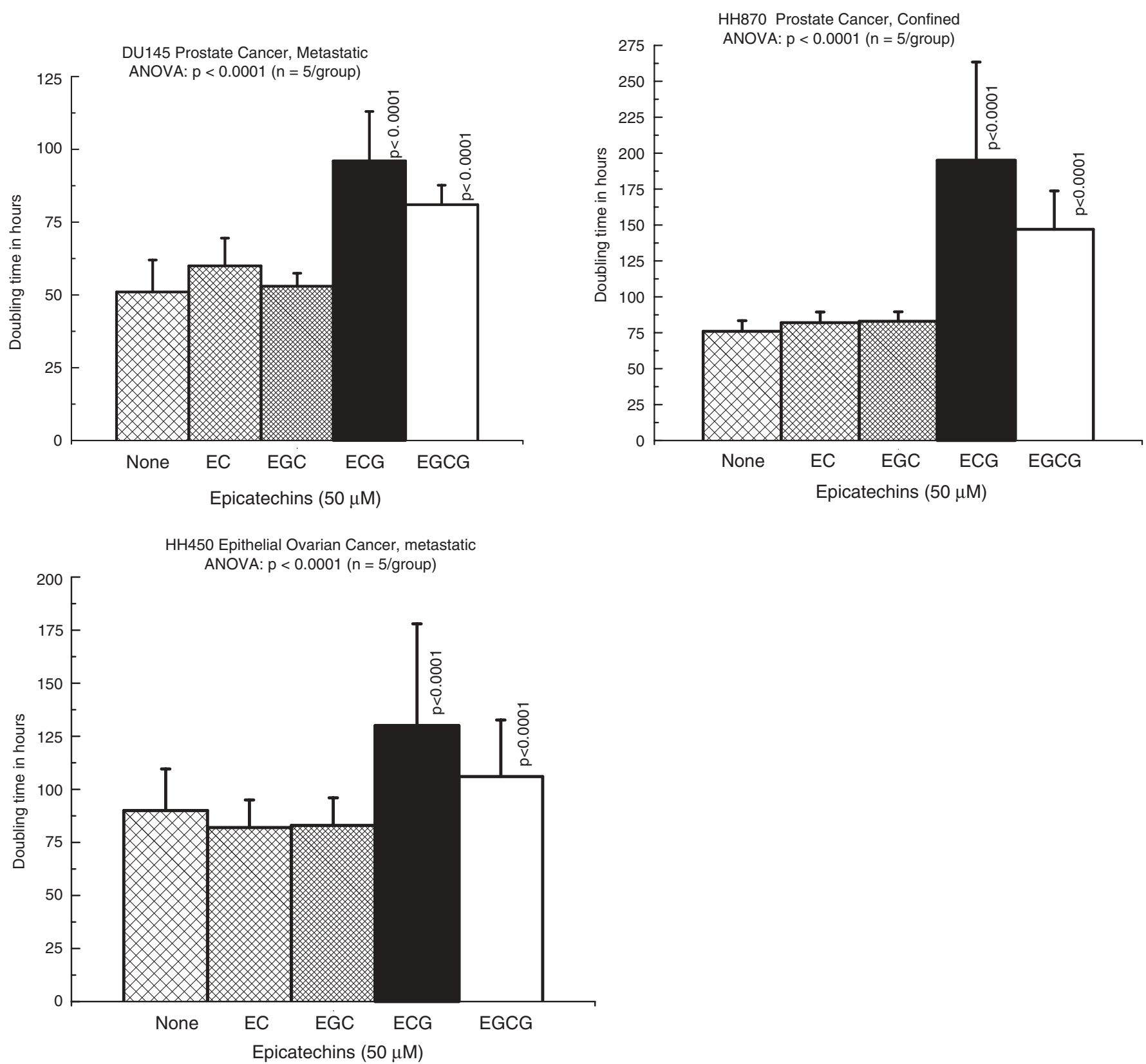

Figure 5. Doubling time of cancer cells seeded $\left(0.25 \times 10^{6}\right.$ per line) into flasks containing culture medium (RPMI- 1640 with $9 \%$ FBS-antibiotics) with or without catechins $(50 \mu \mathrm{M})(n=5$ per treatment). When untreated cells reached confluency, cells from each flask were harvested and viable/dead cells were counted. Vertical bars refer to standard deviation. The mean doubling time was calculated from the mean of five viable cell counts. $P$-values were obtained with pairwise comparison and ANOVA.

\section{Results}

\section{ECG as a Better Growth Suppressor Than EGCG: Microscopic Observations}

Organ-confined prostate cancer cell line HH870 and primary and metastatic epithelial ovarian cancer cell lines (HH450 and HH639) seeded $\left(2.5 \times 10^{5}\right.$ cells $)$ in flasks with or without various concentrations $(25,50,75$ or $100 \mu \mathrm{M})$ of ECG or EGCG were photographed under a light microscope after the untreated control cells reached confluency (Fig. 3). Both
ECG and EGCG significantly affected the density of each cell line at or above $75 \mu \mathrm{M}$. The decrease in cell density at higher concentrations is much pronounced for ECG than for EGCG, a finding significant considering recommendations of clinical trials with EGCG (19).

\section{ECG Suppresses Viable Cell Density Better Than EGCG}

The mean density or viable cell number (in millions) ( $n=5$ per treatment) of different cell lines was examined with or without 
Table 1. Four different epicatechins $(50 \mu \mathrm{M})$ on cell number, cell cycles and mean doubling time of prostate and epithelial ovarian cancer cell lines

\begin{tabular}{|c|c|c|c|c|c|}
\hline Parameters & Control & $\mathrm{EC}$ & ECG & EGC & EGCG \\
\hline \multicolumn{6}{|c|}{ Organ-confined prostate cancer (HH870), $186 \mathrm{~h} *$ for confluent growth of untreated cells } \\
\hline Number of flasks & 5 & 5 & 5 & 5 & 5 \\
\hline Initial seeding & $0.25 \times 10^{6}$ & $0.25 \times 10^{6}$ & $0.25 \times 10^{6}$ & $0.25 \times 10^{6}$ & $0.25 \times 10^{6}$ \\
\hline Cell number ${ }^{\dagger}$ & $1.39 \times 10^{6}$ & $1.22 \times 10^{6}$ & $0.54 \times 10^{6}$ & $1.19 \times 10^{6}$ & $0.76 \times 10^{6}$ \\
\hline Fold increase (approx.) & $>2$ & $>2$ & 1 & $>2$ & $>1$ \\
\hline Number of cell cycles & 2.5 & 2 & 1 & 2 & 1.5 \\
\hline Dead cell count & $0.22 \times 10^{6}$ & $0.12 \times 10^{6}$ & $0.1 \times 10^{6}$ & $0.2 \times 10^{6}$ & $0.16 \times 10^{6}$ \\
\hline Mean doubling time & $76 \mathrm{~h}$ & $82 \mathrm{~h}$ & $195 \mathrm{~h}$ & $83 \mathrm{~h}$ & $147 \mathrm{~h}$ \\
\hline \multicolumn{6}{|c|}{ Metastatic prostate cancer (DU145), $125 \mathrm{~h}^{*}$ for confluent growth of untreated cells } \\
\hline Number of flasks & 5 & 5 & 5 & 5 & 5 \\
\hline Initial seeding & $0.25 \times 10^{6}$ & $0.25 \times 10^{6}$ & $0.25 \times 10^{6}$ & $0.25 \times 10^{6}$ & $0.25 \times 10^{6}$ \\
\hline Cell number ${ }^{\dagger}$ & $1.56 \times 10^{6}$ & $1.11 \times 10^{6}$ & $0.64 \times 10^{6}$ & $1.31 \times 10^{6}$ & $0.74 \times 10^{6}$ \\
\hline Fold increase (approx.) & $>2$ & $\sim 2$ & $>1$ & $>2$ & $>1$ \\
\hline Number of cell cycles & 2.5 & 2 & 1.3 & 2.4 & 1.6 \\
\hline Dead cell count & $0.45 \times 10^{6}$ & $0.3 \times 10^{6}$ & $0.24 \times 10^{6}$ & $0.34 \times 10^{6}$ & $\mathbf{0}$ \\
\hline Mean doubling time & $51 \mathrm{~h}$ & $60 \mathrm{~h}$ & $96 \mathrm{~h}$ & $53 \mathrm{~h}$ & $81 \mathrm{~h}$ \\
\hline \multicolumn{6}{|c|}{ Epithelial ovarian cancer (HH450), $219 \mathrm{~h}^{*}$ for confluent growth of untreated cells } \\
\hline Number of flasks & 5 & 5 & 5 & 5 & 5 \\
\hline Initial seeding & $0.16 \times 10^{6}$ & $0.16 \times 10^{6}$ & $0.16 \times 10^{6}$ & $0.16 \times 10^{6}$ & $0.16 \times 10^{6}$ \\
\hline Cell number ${ }^{\dagger}$ & $0.93 \times 10^{6}$ & $1.06 \times 10^{6}$ & $0.66 \times 10^{6}$ & $1.06 \times 10^{6}$ & $0.48 \times 10$ \\
\hline Fold increase (approx.) & $>3$ & $>3$ & 3 & $>3$ & $>2$ \\
\hline Number of cell cycles & 2.5 & 2.7 & 1.9 & 2.7 & 1.5 \\
\hline Dead cell count & $0.66 \times 10^{6}$ & $0.40 \times 10^{6}$ & $0.29 \times 10^{6}$ & $0.46 \times 10^{6}$ & $0.14 \times 10$ \\
\hline Mean doubling time & $90 \mathrm{~h}$ & $82 \mathrm{~h}$ & $130 \mathrm{~h}$ & $83 \mathrm{~h}$ & $106 \mathrm{~h}$ \\
\hline \multicolumn{6}{|c|}{ Epithelial ovarian cancer (HH639), $170 \mathrm{~h}^{\ddagger}$ for confluent growth of untreated cells } \\
\hline Number of flasks & 5 & 5 & 5 & 5 & 5 \\
\hline Initial seeding & $0.25 \times 10^{6}$ & $0.25 \times 10^{6}$ & $0.25 \times 10^{6}$ & $0.25 \times 10^{6}$ & $0.25 \times 10^{6}$ \\
\hline Cell number ${ }^{\dagger}$ & $2.1 \times 10^{6}$ & $0.90 \times 10^{6}$ & $0.20 \times 10^{6} *$ & $1.83 \times 10^{6 \dagger}$ & $1.10 \times 10^{6}$ \\
\hline Fold increase (approx.) & 3 & $\sim 3$ & $\mathbf{0}$ & 3 & 2 \\
\hline Number of cell cycles & 3 & $\sim 2$ & $\mathbf{0}$ & 3 & 2 \\
\hline Dead cell count & $0.27 \times 10^{6}$ & $0.16 \times 10^{6}$ & $0.11 \times 10^{6}$ & $0.014 \times 10^{6}$ & $0.30 \times 10^{6}$ \\
\hline Mean doubling time & $56 \mathrm{~h}$ & $124 \mathrm{~h}$ & $\mathbf{0}$ & $51 \mathrm{~h}$ & $88 \mathrm{~h}$ \\
\hline
\end{tabular}

*Four flasks were counted; ${ }^{\dagger}$ mean viable cell count; ${ }^{\dagger}$ three flasks were counted. Significant values are shown in bold.

catechins $(50 \mu \mathrm{M})$ (Fig. 4). The cell density was measured when growth of untreated cells reached confluency. Statistical analysis by ANOVA as well as by pairwise comparison showed that both ECG and EGCG significantly affected the cell density. ECG decreased the cell density of prostate cancer cells DU145, HH870 and ovarian cancer cell line HH639 more potently than EGCG. But EGCG inhibited the growth of ovarian cancer cell line HH450 better than ECG, suggesting the need to determine relative efficacy of ECG and EGCG in clinical trials for different cancers.

\section{Tumor Cell Doubling Time: ECG versus EGCG}

Figure 5 shows the influence of the four epicatechins on cell doubling time. ECG and/or EGCG prolonged the doubling
Table 2. Relative inhibitory potency (IC50) of epicatechin gallate (ECG) and epigallocatechin gallate (EGCG) on organ-confined (HH870) and metastatic (DU145) prostate cancer and ovarian cancer (HH450 and HH639)

\begin{tabular}{ccc}
\hline Tumor cell line & \multicolumn{2}{c}{ IC50 in $\mu \mathrm{M}$} \\
\cline { 3 - 3 } & ECG & EGCG \\
\hline Prostate cancer & & \\
HH870 & 27.44 & 45.43 \\
DU145 & 24.09 & 88.66 \\
Epithelial ovarian cancer & & \\
HH450 & 28.95 & 62.25 \\
HH639 & 29.59 & 42.21 \\
\hline
\end{tabular}




\begin{tabular}{|l|r|r|r|r|r|}
\hline & $\mathbf{0 \mu M}$ & $\mathbf{2 5} \boldsymbol{\mu M}$ & $\mathbf{5 0} \boldsymbol{\mu M}$ & $\mathbf{7 5} \boldsymbol{\mu M}$ & $\mathbf{1 0 0} \boldsymbol{\mu M}$ \\
\hline ECG & & & & & \\
\hline Mean & & $\mathbf{0 . 5 0 4}$ & $\mathbf{0 . 1 3 4}$ & $\mathbf{0 . 0 1 0}$ & $\mathbf{0 . 0 0 2}$ \\
\hline SD & & $\mathbf{0 . 1 8 1}$ & $\mathbf{0 . 0 5 7}$ & $\mathbf{0 . 0 0 4}$ & $\mathbf{0 . 0 0 3}$ \\
\hline $\mathrm{p}$ (two-tail) & & 0.701 & 0.033 & 0.014 & 0.013 \\
\hline EGCG & & & & & \\
\hline Mean & $\mathbf{0 . 9 0 9}$ & $\mathbf{1 . 3 1 9}$ & $\mathbf{1 . 2 3 2}$ & $\mathbf{0 . 5 8 1}$ & $\mathbf{0 . 0 0 3}$ \\
\hline SD & $\mathbf{0 . 3 9 4}$ & $\mathbf{0 . 3 1 9}$ & $\mathbf{0 . 3 7 1}$ & $\mathbf{0 . 1 9 2}$ & $\mathbf{0 . 0 0 4}$ \\
\hline $\mathrm{p}$ (two-tail) & & 0.029 & 0.066 & 0.990 & 0.013 \\
\hline
\end{tabular}

\begin{tabular}{|l|r|r|r|r|r|}
\hline & $\mathbf{0} \mu \mathrm{M}$ & $\mathbf{2 5} \boldsymbol{\mu M}$ & $\mathbf{5 0} \boldsymbol{\mu M}$ & $\mathbf{7 5} \boldsymbol{\mu M}$ & $\mathbf{1 0 0} \boldsymbol{\mu M}$ \\
\hline ECG & & & & & \\
\hline Mean & & $\mathbf{1 . 0 8 5 8}$ & $\mathbf{0 . 1 9 0 0}$ & $\mathbf{0 . 0 0 5 8}$ & $\mathbf{0 . 0 2 3 3}$ \\
\hline SD & & $\mathbf{0 . 5 2 1 4}$ & $\mathbf{0 . 3 0 9 7}$ & $\mathbf{0 . 0 0 5 2}$ & $\mathbf{0 . 0 0 5 8}$ \\
\hline p (two-tail) & 0.223 & 0.008 & 0.0001 & 0.0001 \\
\hline EGCG & & & & & \\
\hline Mean & $\mathbf{1 . 5 9 7 9}$ & $\mathbf{2 . 0 0 2 5}$ & $\mathbf{0 . 7 6 3 3}$ & $\mathbf{0 . 2 5 0 0}$ & $\mathbf{0 . 0 2 4 2}$ \\
\hline SD & $\mathbf{0 . 3 2 4 9}$ & $\mathbf{0 . 1 4 7 5}$ & $\mathbf{0 . 1 4 3 2}$ & $\mathbf{0 . 1 0 4 7}$ & $\mathbf{0 . 0 1 2 6}$ \\
\hline p (two-tail) & 0.037 & 0.0011 & 0.0001 & 0.0001 \\
\hline
\end{tabular}
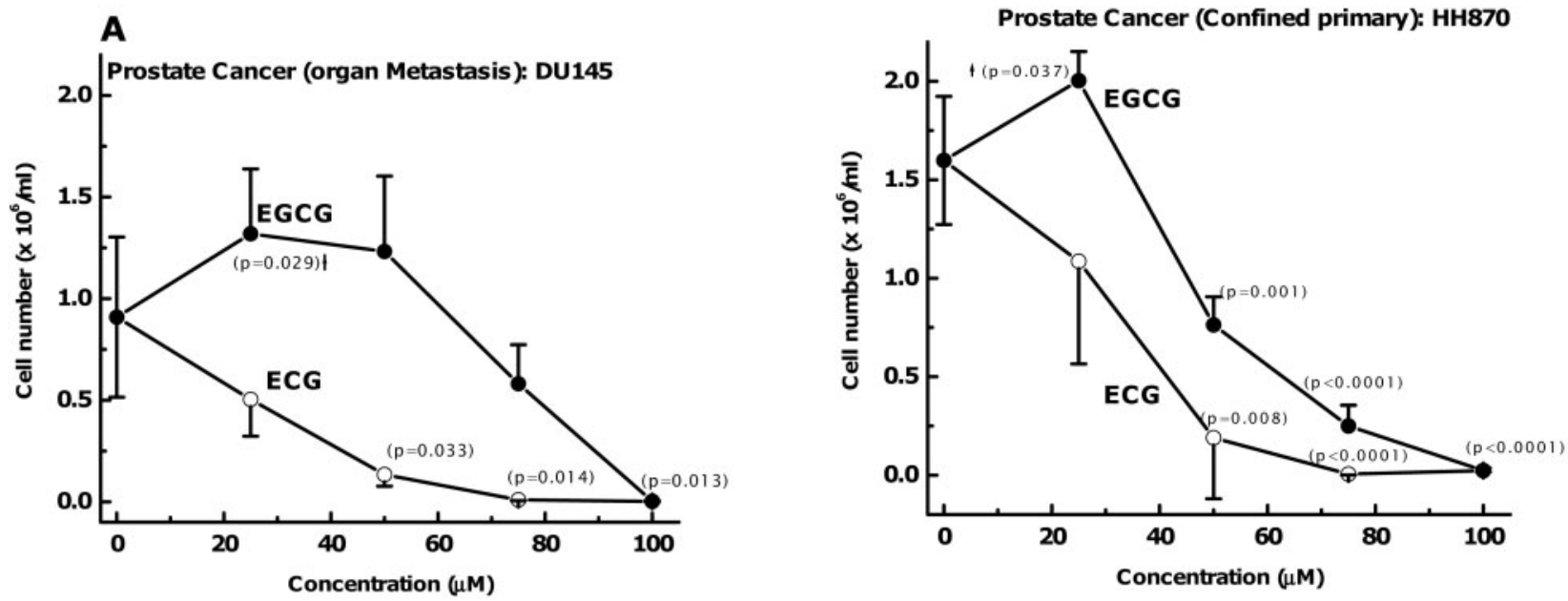

D

C

\begin{tabular}{|l|r|r|r|r|r|}
\hline & $\mathbf{0 \mu M}$ & $\mathbf{2 5} \boldsymbol{\mu M}$ & $\mathbf{5 0} \mu \mathrm{M}$ & $\mathbf{7 5} \boldsymbol{\mu M}$ & $\mathbf{1 0 0} \boldsymbol{\mu M}$ \\
\hline ECG & & & & & \\
\hline Mean & & $\mathbf{1 . 7 5 0 8}$ & $\mathbf{0 . 0 7 8 3}$ & $\mathbf{0 . 0 1 2 5}$ & $\mathbf{0 . 0 0 5 8}$ \\
\hline SD & & 0.1913 & $\mathbf{0 . 0 3 4 1}$ & $\mathbf{0 . 0 0 6 6}$ & $\mathbf{0 . 0 0 1 4}$ \\
\hline p (two-tail) & & 0.0217 & 0.0005 & 0.0004 & 0.0004 \\
\hline EGCG & & & & & \\
\hline Mean & $\mathbf{2 . 8 3 7}$ & $\mathbf{3 . 3 5 0 8}$ & $\mathbf{2 . 0 7 9 2}$ & $\mathbf{0 . 8 8 4 2}$ & $\mathbf{0 . 0 1 0 8}$ \\
\hline SD & $\mathbf{0 . 8 1 9}$ & $\mathbf{0 . 7 0 9}$ & $\mathbf{0 . 2 2 2}$ & $\mathbf{0 . 2 2 0}$ & $\mathbf{0 . 0 0 8}$ \\
\hline p (two-tail) & & 0.378 & 0.077 & 0.0014 & 0.0004 \\
\hline
\end{tabular}

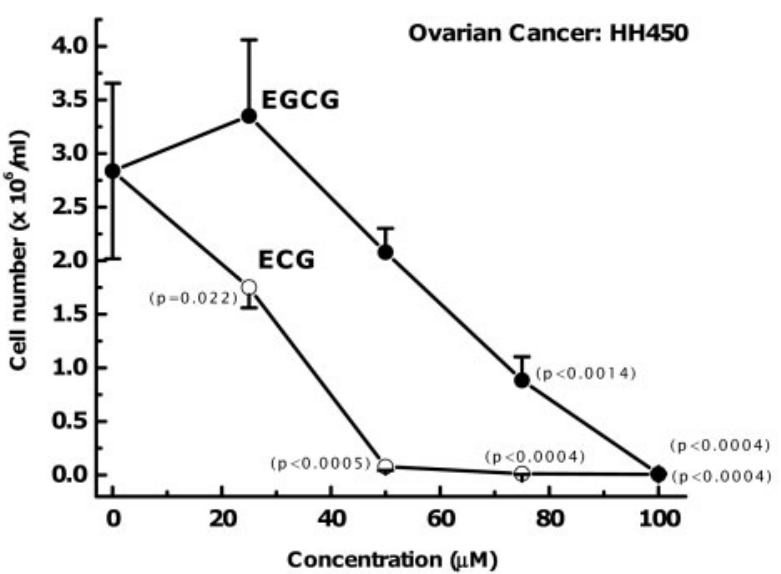

\begin{tabular}{|l|r|r|r|r|r|}
\hline & $0 \mu \mathrm{M}$ & $25 \mu \mathrm{M}$ & $50 \mu \mathrm{M}$ & $\mathbf{7 5} \mu \mathrm{M}$ & $100 \mu \mathrm{M}$ \\
\hline ECG & & & & & \\
\hline Mean & & 1.6242 & 0.0967 & 0.0267 & 0.0100 \\
\hline SD & & 0.7082 & 0.0104 & 0.0138 & 0.0043 \\
\hline p (two-tail) & 0.0964 & 0.0005 & 0.0004 & 0.0004 \\
\hline EGCG & & & & & \\
\hline Mean & 2.7088 & 1.4925 & 1.2650 & $\mathbf{0 . 8 2 4 2}$ & $\mathbf{0 . 0 0 6 7}$ \\
\hline SD & $\mathbf{0 . 7 6 9 9}$ & $\mathbf{0 . 5 8 0 2}$ & $\mathbf{0 . 6 8 1 7}$ & $\mathbf{0 . 1 2 5 4}$ & $\mathbf{0 . 0 0 1 4}$ \\
\hline p (two-tail) & 0.0422 & 0.0386 & 0.0015 & 0.0004 \\
\hline
\end{tabular}

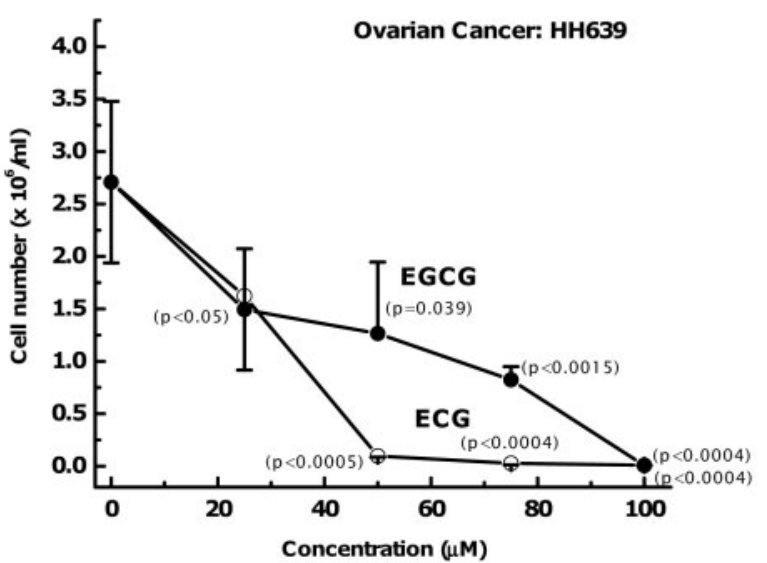

Figure 6. Suppression of cell growth by ECG and EGCG. (A) DU145; (B) HH870; (C) HH450; (D) HH639. Cells $\left(0.25 \times 10^{6}\right.$ per line) were seeded in flasks containing culture medium (RPMI-1640 with 9\% FBS-antibiotics) with or without ECG or EGCG at concentrations of 0, 25, 50, 75 and 100 $\mu$ M (three flasks for each dose). Mean (circles) and standard deviation (vertical lines) are represented. When untreated cells reached confluency, cell monolayers in each flask were photographed under a light microscope, harvested and counted. The suppressive effect on cell density was striking at higher concentrations of ECG and EGCG. At $25 \mu \mathrm{M}$ of EGCG, cell counts for HH870 and DU145 were significantly higher than control values. $P$-values indicate significant differences between mean values of treated and untreated cells. 


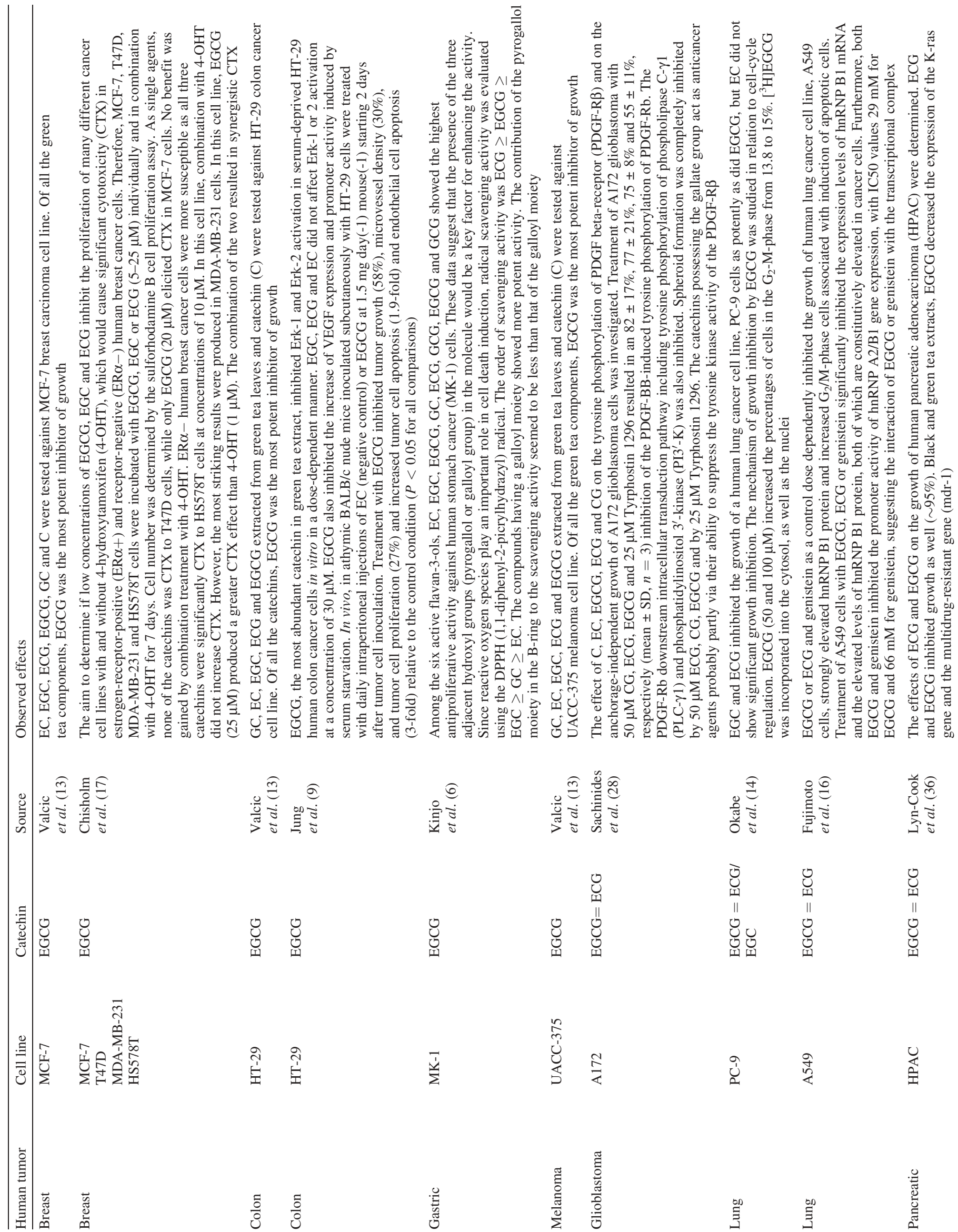




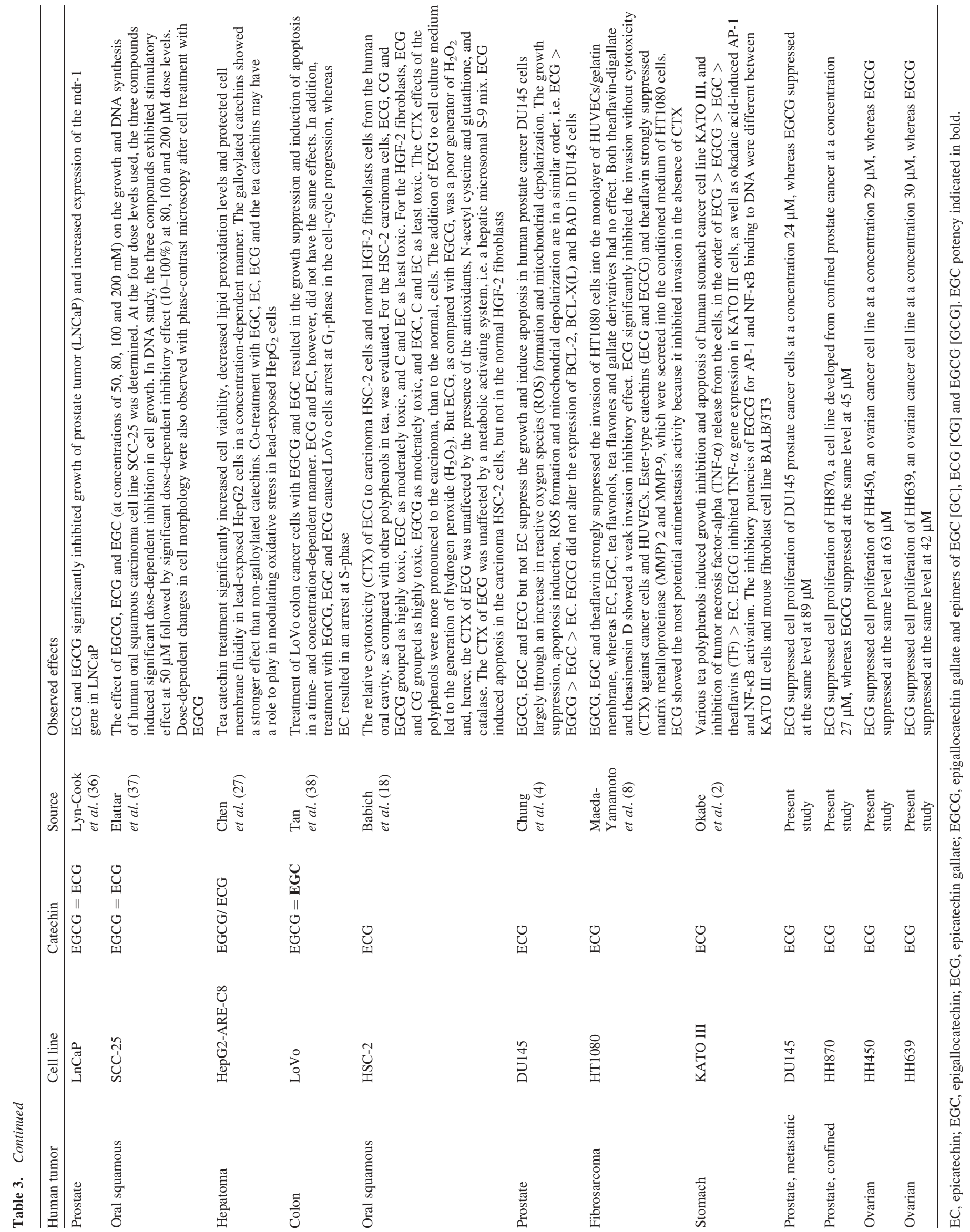


time of CaP cell lines DU145 and HH870 and EOC line HH450. No doubling was observed for HH639 cells treated with ECG; instead cell number decreased, indicating cell death. Table 1 summarizes the effects of EC, ECG, EGC and EGCG on viability, doubling time and cycling of the four cell lines. Untreated cells from each line reached confluency in about 2.5 cell cycles. EC did not affect the proliferation of DU145, HH870 or HH450 cells but it reduced the proliferation of HH639 cells by half $(P<0.05)$ and prevented their confluent growth (Table 1). EGC did not affect the proliferation of any cell line (Table 1), whereas EGCG arrested proliferation of all four lines. ECG, followed by EGCG, was the most potent inhibitor of cell growth and cycling.

\section{Dosimetric Analysis of Growth to Tumor cells: IC50 of ECG is Superior to EGCG}

Proliferation of each cell line ( $n=3$ per treatment) was monitored with or without ECG or EGCG at concentrations of $0,25,50,75$ and $100 \mu \mathrm{M}$. The dosimetric results plotted in Fig. 6 shows concentration-dependent suppression of cell growth by ECG and EGCG. The suppressive effect on cell density was striking at higher concentrations of ECG and EGCG. ECG was a more potent inhibitor of cell growth than EGCG. At $25 \mu \mathrm{M}$ of EGCG, cell numbers for HH870 and DU145 were significantly higher than control values. Based on the results plotted in Fig. 6, IC50 values were calculated. The IC50 values are 24-30 $\mu \mathrm{M}$ for ECG, versus 42-89 $\mu \mathrm{M}$ for EGCG (Table 2). ECG suppressed growth at all higher concentrations tested (Fig. 6), whereas EGCG significantly $(P<0.05)$ enhanced proliferation of $\mathrm{CaP}$ cells at $25 \mu \mathrm{M}$, a finding relevant to chemoprevention trials with EGCG only.

\section{Discussion}

Green tea is widely consumed in Japan and China and its polyphenolic components have a chemopreventive effect against cancer in vitro and in vivo (39). A cup of green tea contains 100-150 mg catechins, of which $8 \%$ are EC, 15\% are EGC, $15 \%$ are ECG and $50 \%$ are EGCG (40). Although numerous investigations have shown the role of EGCG in cancer chemoprevention, only a few studies have attempted to compare the relative antitumor efficacy of all four catechins (Table 3). When we used a systematic approach to assess the effect of various catechins on cell lines derived from gender-based cancers, we found that each catechin's antitumor activity depended on the type of tumor. EGCG was not always the most potent chemopreventive agent.

Most of the earlier literature (Table 3) indicates that EGCG is the most potent growth inhibitor of cell lines from glioblastoma, melanoma and cancers of the breast, colon, lung, prostate (androgen-receptor-positive), pancreas, liver and mouth. EGCG prevents proliferation of DU145 cells by arresting the cell cycle at $\mathrm{G}_{0} / \mathrm{G}_{1}$-phase (19). Gupta and others (26) have documented that $G_{0} / G_{1}$-phase arrest is independent of p53 mutation, and EGCG treatment of DU145 induces the cyclin kinase inhibitor WAF1/p21. These observations suggest that EGCG imposes a cell-cycle checkpoint (19). However, our results showed that ECG may be more potent than EGCG for inhibition of primary and metastatic CaP and EOC cells (Fig. 4, Tables 1 and 2). ECG significantly reduced cell proliferation (Table 1, Figs 2 and 3) and increased mean doubling time (Table 1, Fig. 4).

The in vitro effect of chemopreventive agents can be studied when tumor cells are in a matrix $(1,4,27)$ or in a suspension $(28,29)$. We used the suspension method because it exposes the entire cell surface to the chemotherapeutic agent. Our findings confirm an earlier report that used the matrix method to show that ECG is more potent than EGCG in suppressing the proliferation of DU145 CaP cells (4). Thus reported differences in the relative efficacy of different catechins may not be due to differences in methodology.

Not all tumor cells are killed by catechins. In our study, ECG $(50 \mu \mathrm{M})$ induced death of most but not all HH639 cells. Doubling ECG's IC50 concentration might increase the tumor kill rate if ECG does not epimerize to $\mathrm{CG}$. Our in vitro dose of $100 \mu \mathrm{M}$ is equivalent to $29 \mathrm{mg}$ (EC/EGC) to $45 \mathrm{mg}$ (EGCG/ ECG), far less than the $100-150 \mathrm{mg}$ (50\% of which is EGCG) in one cup of green tea. However, Lee et al. (41) reported that plasma levels of EGCG and EGC in healthy volunteers increased to 78 and $223 \mathrm{ng} \mathrm{ml}^{-1}$, respectively, $20 \mathrm{~min}$ after drinking brewed green tea ( $1.2 \mathrm{~g}$ of tea solids in $200 \mathrm{ml}$ hot water). This suggests that drinking more than 10 cups of green tea may be necessary to maintain a plasma concentration of EGCG equivalent to that used in vitro by a dose of $50 \mu \mathrm{M}$ or $22.5 \mathrm{mg}$. Kaegi (42) suggested a daily intake of 13 cups of green tea as a chemopreventive measure. Because this level of tea consumption is impractically high, chemoprevention of cancer with catechins may require administration of the appropriate catechin in a purified form.

In conclusion it may be stated that both green and black tea polyphenols are important components of antitumor aspect of complementary and alternative medicine (CAM), which play a significant role in the American health care system and in patients who suffer from chronic problems (43). While green tea catechin gallates such as EGCG and ECG possess potent antitumor activities, their epimers, commonly found in black tea, act as potent inhibitor of proteases involved in replication of viruses, including coronoviruses (44). There is a need to understand preventive and therapeutic potential of catechin gallates from both green and black teas. We are currently designing a phase I chemopreventive study to examine the effects of purified EGCG and ECG in patients who have been chosen observational management of organ-confined prostate cancer.

\section{Acknowledgments}

This study is supported by the grants received from Santa Monica Research Foundation, Associates of Breast and Prostate Cancer at John Wayne Cancer Institute and grants from 
National Institute of Health, CA107831 and CA107316. We thank Miss Gwen Berry for valuable editorial assistance, $\mathrm{Mr}$ Adam Blackstone for preparation of Fig. 1 and Miss Vaishaly Ramasamy for critically going through the manuscript.

\section{REFERENCES}

1. USDA Database for the Flavonoid Content of Selected Foods, Prepared by the Nutrient Data Laboratory, Food Composition Laboratory, Beltsville Human Nutrition Research Center, Agricultural Research Service, US Department of Agriculture, Belsville, MD, 2003.

2. Okabe S, Ochiai Y, Aida M, Park K, Kim SJ, Nomura T, et al. Mechanistic aspects of green tea as a cancer preventive: effect of components on human stomach cancer cell lines. Jpn J Cancer Res 1999;90:733-9.

3. Chen C, Yu R, Owuor ED, Kong AN. Activation of antioxidant-response element (ARE), mitogen-activated protein kinases (MAPKs), caspases by major green tea polyphenol components during cell survival and death. Arch Pharm Res 2000;23:605-12.

4. Chung LY, Cheung TC, Kong SK, Fung KP, Choy YM, Chan ZY, et al. Induction of apoptosis by green tea catechins in human prostate cancer DU145 cells. Life Sci 2001;68:1207-14.

5. Tan X, Hu D, Li S, Han Y, Zhang Y, Zhou D. Differences of four catechins in cell cycle arrest and induction of apoptosis in LoVo cells. Cancer Lett 2000;158:1-6.

6. Kinjo J, Nagao T, Tanaka T, Nonaka G, Okawa M, Nohara T, et al. Activity-guided fractionation of green tea extract with antiproliferative activity against human stomach cancer cells. Biol Pharm Bull 2002;25:1238-40.

7. Demeule M, Brossard M, Page M, Gingras D, Beliveau R. Matrix metalloproteinase inhibition by green tea catechins. Biochim Biophys Acta 2000;1478:51-60.

8. Maeda-Yamamoto M, Kawahara H, Tahara N, Tsuji K, Hara Y, Isemura M. Effects of tea polyphenols on the invasion, matrix metalloproteinases activities of human fibrosarcoma HT1080 cells. J Agric Food Chem 1999;47:2350-4.

9. Jung YD, Kim MS, Shin BA, Chay KO, Ahn BW, Liu W, et al. EGCG, a major component of green tea, inhibits tumour growth by inhibiting VEGF induction in human colon carcinoma cells. Br J Cancer 2001;84:844-50.

10. Kondo T, Ohta T, Igura K, Hara Y, Kaji K. Tea catechins inhibit angiogenesis in vitro, measured by human endothelial cell growth, migration, tube formation, through inhibition of VEGF receptor binding. Cancer Lett 2002;180:139-44.

11. Jodoin J, Demeule M, Beliveau R. Inhibition of the multidrug resistance P-glycoprotein activity by green tea polyphenols. Biochim Biophys Acta 2002;1542:149-59.

12. Liang G, Zhang S, Huang ZM, Tang AZ. [MDR-reversing effect of two components of catechin on human hepatocellular carcinoma BEL-7404/ Adr in vitro] Ai Zheng 2004;23:401-5.

13. Valcic S, Timmermann BN, Alberts DS, Wachter GA, Krutzsch M, Wymer J, et al. Inhibitory effect of six green tea catechins and caffeine on the growth of four selected human tumor cell lines. Anticancer Drugs 1996;7:461-8.

14. Okabe S, Suganuma M, Hayashi M, Sueoka E, Komori A, Fujiki H. Mechanisms of growth inhibition of human lung cancer cell line, PC-9, by tea polyphenols. Jpn J Cancer Res 1997;88:639-43.

15. Elattar TM, Virji AS. Effect of tea polyphenols on growth of oral squamous carcinoma cells in vitro. Anticancer Res 2000;20:3459-65.

16. Fujimoto N, Sueoka N, Sueoka E, Okabe S, Suganuma M, Harada M, et al. Lung cancer prevention with (-)-epigallocatechin gallate using monitoring by heterogeneous nuclear ribonucleoprotein B1. Int J Oncol 2002;20: 1233-9.

17. Chisholm K, Bray BJ, Rosengren RJ, Tamoxifen. and epigallocatechin gallate are synergistically cytotoxic to MDA-MB-231 human breast cancer cells. Anticancer Drugs 2004;15:889-97.

18. Babich H, Krupka ME, Nissim HA, Zuckerbraun HL. Differential in vitro cytotoxicity of (-)-epicatechin gallate (ECG) to cancer, normal cells from the human oral cavity. Toxicol In Vitro 2005;19:231-42.

19. Adhami VM, Ahmad N, Mukhtar H. Molecular targets for green tea in prostate cancer prevention. J Nutr 2003;133:2417S-2424S.

20. Ikeda I, Imasato Y, Sasaki E, Nakayama M, Nagao H, Takeo T, et al. Tea catechins decrease micellar solubility and intestinal absorption of cholesterol in rats. Biochim Biophys Acta 1992;1127:141-6.

21. Tao P. [The inhibitory effects of catechin derivatives on the activities of human immunodeficiency virus reverse transcriptase and DNA polymerases] Zhongguo Yi Xue Ke Xue Yuan Xue Bao. 1992;14: 334-8.

22. Makimura M, Hirasawa M, Kobayashi K, Indo J, Sakanaka S, Taguchi T, et al. Inhibitory effect of tea catechins on collagenase activity. J Periodontol 1993;64:630-6.

23. Salah N, Miller NJ, Paganga G, Tijburg L, Bolwell GP, Rice-Evans C. Polyphenolic flavanols as scavengers of aqueous phase radicals, as chain-breaking antioxidants. Arch Biochem Biophys 1995;322:339-46.

24. Aucamp J, Gaspar A, Hara Y, Apostolides Z. Inhibition of xanthine oxidase by catechins from tea (Camellia sinensis). Anticancer Res 1997;17: 4381-5.

25. Selvan SR, Cornforth AN, Rao NP, Reid YA, Schiltz PM, Liao RP, et al. Establishment and characterization of a human primary prostate carcinoma cell line, HH870. Prostate 2005;63:91-103.

26. Gupta S, Ahmad N, Nieminen AL, Mukhtar H. Growth inhibition, cellcycle dysregulation, induction of apoptosis by green tea constituent (-)-epigallocatechin-3-gallate in androgen-sensitive and androgeninsensitive human prostate carcinoma cells. Toxicol Appl Pharmacol 2000;164:82-90.

27. Chen L, Yang X, Jiao H, Zhao B. Tea catechins protect against leadinduced cytotoxicity, lipid peroxidation, membrane fluidity in HepG2 cells. Toxicol Sci 2002;69:149-56.

28. Sachinidis A, Seul C, Seewald S, Ahn H, Ko Y, Vetter H. Green tea compounds inhibit tyrosine phosphorylation of PDGF beta-receptor, transformation of A172 human glioblastoma. FEBS Lett 2000;471: $51-5$.

29. Kennedy DO, Nishimura S, Hasuma T, Yano Y, Otani S, Matsui-Yuasa I. Involvement of protein tyrosine phosphorylation in the effect of green tea polyphenols on Ehrlich ascites tumor cells in vitro. Chem Biol Interact 1998;110:159-72.

30. Chen ZP, Schell JB, Ho CT, Chen KY. Green tea epigallocatechin gallate shows a pronounced growth inhibitory effect on cancerous cells but not on their normal counterparts. Cancer Lett 1998;129:173-9.

31. Mukhtar H, Ahmad N. Green tea in chemoprevention of cancer. Toxicol Sci 1999;52:111-17.

32. Suganuma M, Okabe S, Sueoka N, Sueoka E, Matsuyama S, Imai K, et al. Green tea and cancer chemoprevention. Mutat Res 1999;428:339-44.

33. Hsu S, Lewis JB, Borke JL, Singh B, Dickinson DP, Caughman GB, et al. Chemopreventive effects of green tea polyphenols correlate with reversible induction of p57 expression. Anticancer Res 2001;21:3743-8.

34. Jin CF, Shen SR Sr, Zhao BL. Different effects of five catechins on 6-hydroxydopamine-induced apoptosis in PC12 cells. J Agric Food Chem 2001;49:6033-8.

35. Nie G, Jin C, Cao Y, Shen S, Zhao B. Distinct effects of tea catechins on 6-hydroxydopamine-induced apoptosis in PC12 cells. Arch Biochem Biophys 2002;397:84-90.

36. Lyn-Cook BD, Rogers T, Yan Y, Blann EB, Kadlubar FF, Hammons GJ. Chemopreventive effects of tea extracts, various components on human pancreatic and prostate tumor cells in vitro. Nutr Cancer 1999;35:80-6.

37. Elattar TM, Virji AS. Effect of tea polyphenols on growth of oral squamous carcinoma cells in vitro. Anticancer Res 2000;20:3459-65.

38. Tan X, Zhou D, Zhang Y, Jiang B. [Effects of different catechins on cell cycle arrest, induction of apoptosis in LoVo cells] Zhonghua Yu Fang Yi Xue Za Zhi. 2000;34:333-5.

39. Yang CS, Maliakal P, Meng X. Inhibition of carcinogenesis by tea. Ann Rev Pharmacol Toxicol 2002;42:25-54.

40. Muramatsu K, Ogun Il, Isemura M, Sugiyama K, Yamamoto-Maeda M. Health Science of Tea. Tokyo: Japan Scientific Societies Press, 2002, 52-64.

41. Lee M-J., Lambert JD, Prabhu S, Meng X, Lu H, Maliakal P, et al. Delivery of tea polyphenols to the oral cavity by green tea leaves and black tea extract. Cancer Epidem Biomark Prevent 2004;13:132-7.

42. Kaegi E. Unconventional therapies for cancer: 2 Green Tea. Can Med Assoc J 1998;158:1033-5.

43. Goldstein M, Brown ER. The use of complementary, alternative medicine among California adults with and without cancer. Evid Based Complement Alternat Med 2005;2:557-65.

44. Chen CN, Lin CPC, Huang KK, Chen WC, Hsieh HP, Liang PH, et al. Inhibition of SARS-CoV 3C-like protease activity by Theaflavin3,3'digallate (TF3). Evid Based Complement Alternat Med 2005;2: 209-15.

Received July 25, 2005; accepted January 24, 2006 


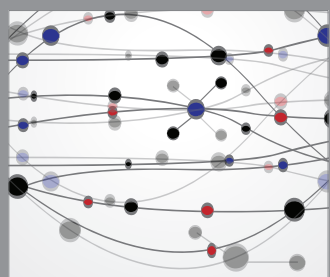

The Scientific World Journal
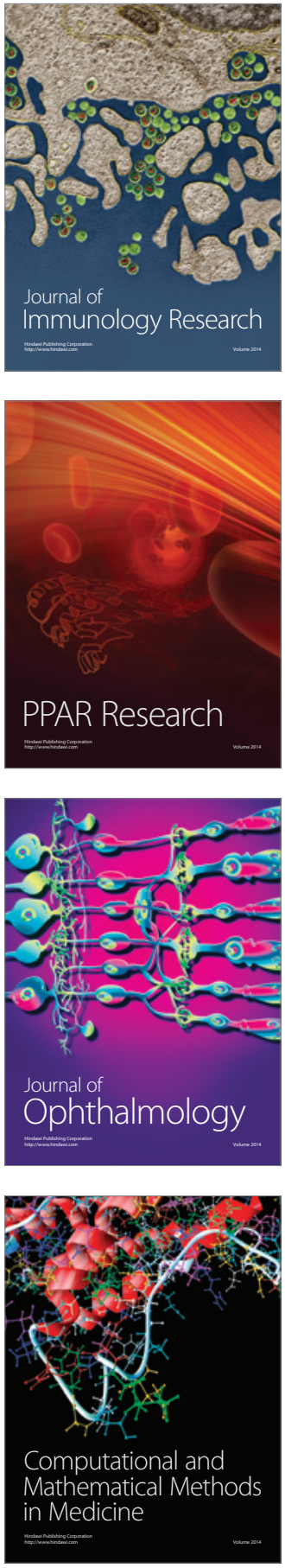

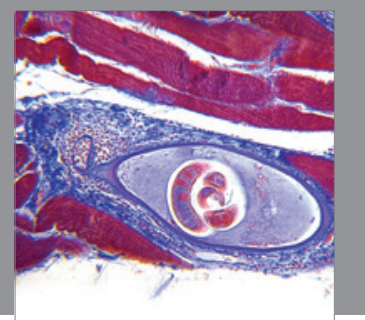

Gastroenterology

Research and Practice
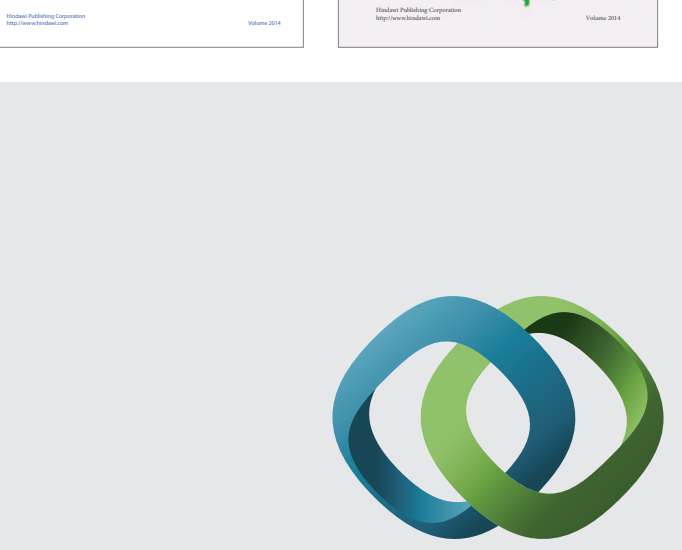

\section{Hindawi}

Submit your manuscripts at

http://www.hindawi.com
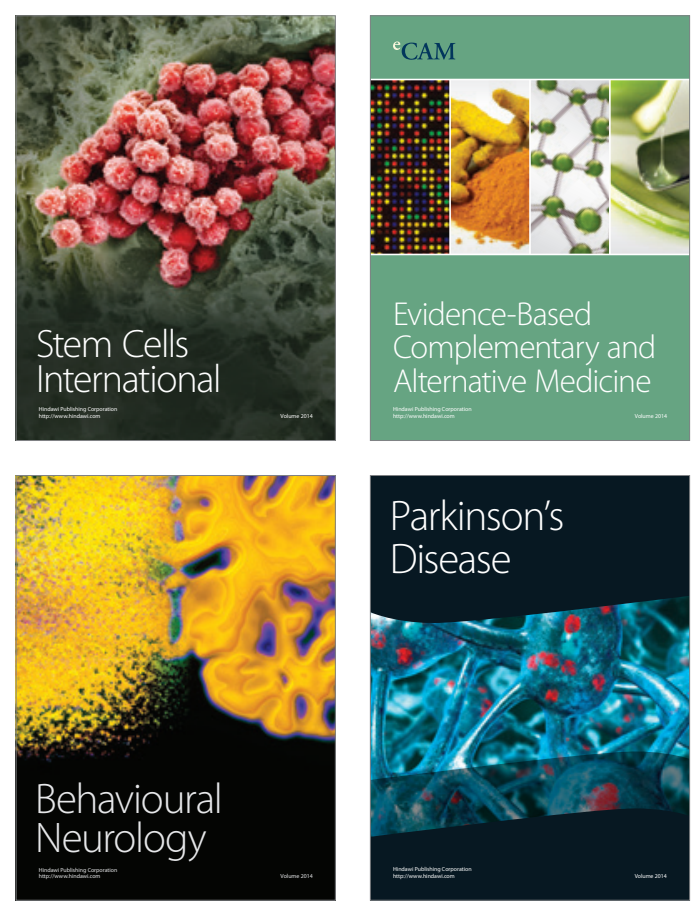

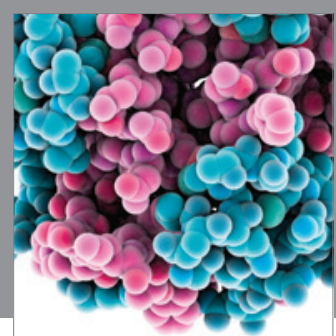

Journal of
Diabetes Research

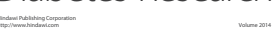

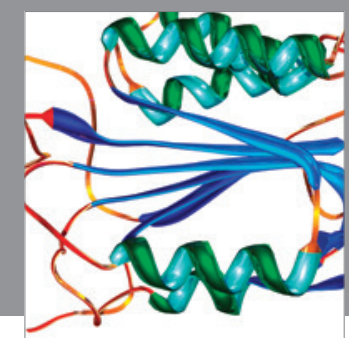

Disease Markers
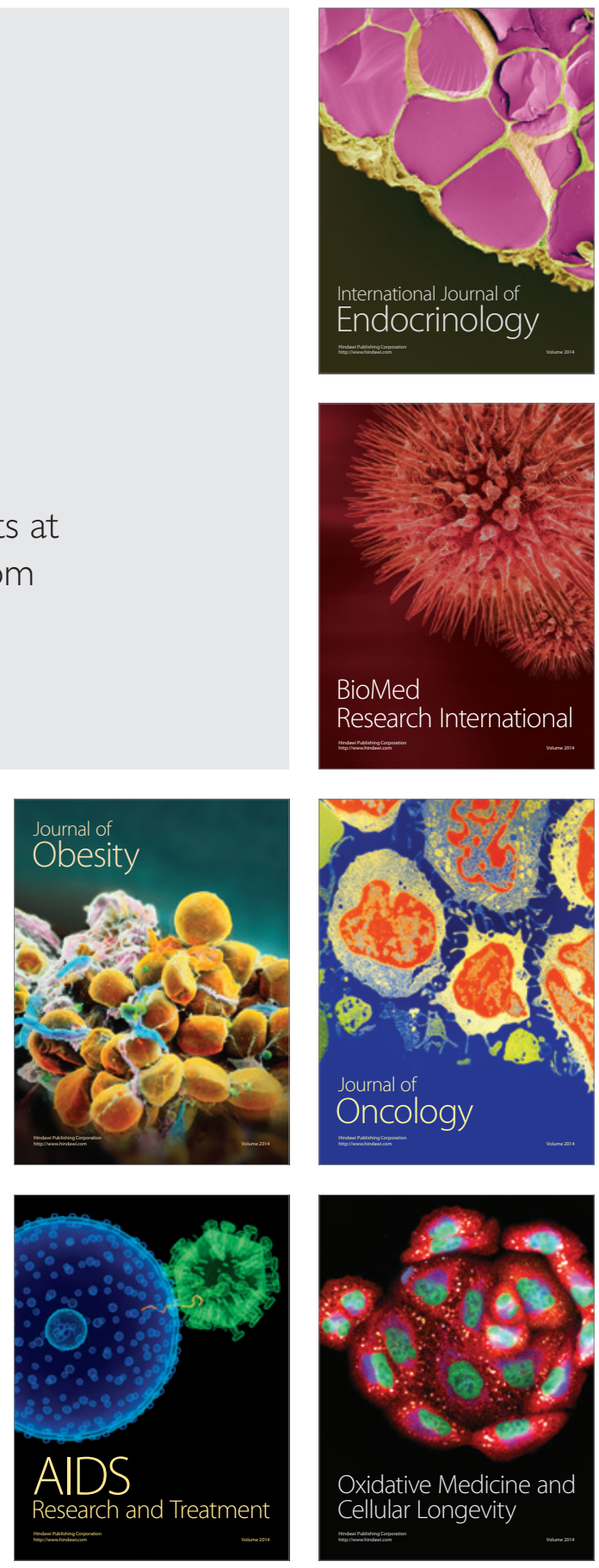